\title{
A journey through the microscopic ages of DNA replication
}

\author{
Marius Reinhart $^{1} \cdot$ M. Cristina Cardoso ${ }^{1}$
}

Received: 3 November 2016 / Accepted: 1 December 2016/Published online: 9 December 2016

(C) The Author(s) 2016. This article is published with open access at Springerlink.com

\begin{abstract}
Scientific discoveries and technological advancements are inseparable but not always take place in a coherent chronological manner. In the next, we will provide a seemingly unconnected and serendipitous series of scientific facts that, in the whole, converged to unveil DNA and its duplication. We will not cover here the many and fundamental contributions from microbial genetics and in vitro biochemistry. Rather, in this journey, we will emphasize the interplay between microscopy development culminating on super resolution fluorescence microscopy (i.e., nanoscopy) and digital image analysis and its impact on our understanding of DNA duplication. We will interlace the journey with landmark concepts and experiments that have brought the cellular DNA replication field to its present state.
\end{abstract}

Keywords DNA · DNA replication · Replication foci · Replicon $\cdot$ Replisome $\cdot$ Super resolution microscopy

\section{The (very) early years}

Long after water-filled glass bowls were used to read small letters (Singer 1914), a simple single lens microscope started the microscopic revolution (Bacon 1267) (see Table 1 and Fig. 1). Spurred throughout the ages by accidental inventions

Handling Editor: Reimer Stick

M. Cristina Cardoso

cardoso@bio.tu-darmstadt.de

1 Cell Biology and Epigenetics, Department of Biology, Technische Universität Darmstadt, Schnittspahnstrasse 10, 64287 Darmstadt, Germany (van der Aa 1851), leaps by Galileo (Galilei 1610), and Hooke (1665), it was not until Carl Zeiss started to mass-produce microscopes in 1847 that DNA observation started to take off. Simultaneously, Mendel studied 29,000 pea plants (1866) and Haeckel postulated the containment of hereditary traits in the nucleus (1866) (Dahm 2008; Haeckel 1866), while Miescher put the microscope to good use and purified the nuclei and observed DNA (Miescher 1871). Köhler's gamechanging illumination technique (Köhler 1893) helped to perfect Zeiss UV-microscope together with Siedentopf in 1908. In 1927, shortly after Levene described the nucleic acid structure (1919), Koltsov postulated the semiconservative replication idea (Soyfer 2001).

\section{The race down to the DNA structure and duplication}

Phase contrast microscopy (Zernike 1955) and DNA X-ray diffraction images (Astbury 1947) Franklin, 1952, "Photo 52 ") lead to fantastic images, new discoveries, and the description of the double helix DNA structure (Watson and Crick 1953). Meselson and Stahl ingeniously demonstrated the semiconservative mode of DNA replication (Meselson and Stahl 1958). The theoretical description of a confocal microscope and the first practical application of a Nipkow disk in microscopy (Egger and Petrán̆ 1967; Petráň et al. 1968) were clear landmarks of the microscopy revolution.

Radioactive labeling and autoradiography allowed Cairns to observe DNA unwinding and the replication fork (Cairns 1963), and Huberman and Riggs observed similar replication structures in mammalian chromosomes (Huberman and Riggs 1966) and Okazaki described the lagging strand synthesis and "its" fragments (Okazaki et al. 1968; Okazaki and Okazaki 1969; Sugimoto et al. 1969; Sugimoto et al. 1968). 
Table 1 Chronological list of landmarks in microscopy and DNA replication

\begin{tabular}{|c|c|c|}
\hline Year & Landmark & Author \\
\hline 63 & Water filed glass bowls to read small letters & (Singer 1914) \\
\hline 1267 & The first simple microscope & (Bacon 1267) \\
\hline 1590 & $\begin{array}{l}\text { Accidental discovery of the compound microscope with two (or more) lenses by } \\
\text { Zacharias Janssen }\end{array}$ & (van der Aa 1851) \\
\hline 1610 & "Microscope" with $\times 1000$ magnification & (Galilei 1610) \\
\hline 1665 & "Micrographia" & (Hooke 1665; Singer 1914) \\
\hline 1847 & First "mass produced" microscopes in 1847 & \\
\hline 1866 & Hereditary traits in 29,000 pea plants & (Mendel 1866) \\
\hline 1866 & Hereditary traits contained in the nucleus & (Dahm 2008; Haeckel 1866) \\
\hline 1871 & Purified nuclei for the first time and observed DNA & (Miescher 1871) \\
\hline 1893 & Ein neues Beleuchtungsverfahren für mikrophotographische Zwecke & (Köhler 1893) \\
\hline 1907 & On the absorption of antibodies & \\
\hline 1908 & First fluorescence microscopes based on UV-microscopy & \\
\hline 1919 & Identification of the nucleic acid structure & \\
\hline 1927 & "Replicate in a semiconservative fashion using each strand as a template" & (Soyfer 2001) \\
\hline 1932 & Discovery of the electron microscope & $\begin{array}{l}\text { (Knoll and Ruska 1932a; Knoll and Ruska } \\
\text { 1932b) }\end{array}$ \\
\hline 1947 & DNA X-ray diffraction images & (Astbury 1947) \\
\hline 1953 & X-ray diffraction "Photo 51" & (Watson and Crick 1953) \\
\hline 1953 & Discovery of the double-helix DNA structure & (Watson and Crick 1953) \\
\hline 1953 & Discovery of phase contrast microscopy & (Zernike 1955) \\
\hline 1958 & Confirmation of the semiconservative DNA replication model & (Meselson and Stahl 1958) \\
\hline 1957 & Discovery of the confocal microscope & (Minsky 1961) \\
\hline 1962 & Extraction, purification, and properties of GFP & (Shimomura et al. 1962) \\
\hline 1963 & DNA unwinding for replication and "replication fork" & (Cairns 1963) \\
\hline 1966 & Autoradiography of chromosomal DNA fibers from Chinese hamster cells. & (Huberman and Riggs 1966) \\
\hline 1966 & On the mechanism of DNA replication in mammalian chromosomes & (Huberman and Riggs 1968) \\
\hline 1967 & First practical application of the "Nipkow disk" in confocal microscopy & (Egger and Petráň 1967; Petráň et al. 1968) \\
\hline 1968 & Mechanism of DNA chain growth. I. Possible discontinuity and unusual secondary & (Okazaki et al. 1968) \\
\hline
\end{tabular}

1968 Mechanism of DNA chain growth, II. Accumulation of newly synthesized short chains in $E$. coli infected with ligase-defective T4 phages.

1969 Duration of the cell cycle

1969 Mechanism of DNA chain growth, III. Equal annealing of T4 nascent short DNA chains with the separated complementary strands of the phage DNA

1969 Mechanism of DNA chain growth. IV. Direction of synthesis of T4 short DNA chains as revealed by exonucleolytic degradation.

1972 Bidirectional Replication of Simian Virus 40 DNA

1974-1979 Fork speed, replication speed, and replicon sizes

(Sugimoto et al. 1968)

(Van Dilla et al. 1969)

(Sugimoto et al. 1969)

(Okazaki and Okazaki 1969)

(Danna and Nathans 1972)

(Kriegstein and Hogness 1974; Taylor 1977; Taylor and Hozier 1976; Wilson and Wilson 1975; Yurov 1977; Yurov 1978; Yurov 1979; Yurov and Liapunova 1977)

1975 Continuous cultures of fused cells secreting antibody of predefined specificity.

1986 Structural organizations of replicon domains during DNA synthetic phase in the mammalian nucleus

1989 Three distinctive replication patterns

1992 Dynamic organization of DNA replication in mammalian cell nuclei spatially and temporally defined replication of chromosome

$1992 \quad$ Progression of DNA synthesis

(Nakamura et al. 1986)

(Nakayasu and Berezney 1989)

(O’Keefe et al. 1992)

(Rizzoli et al. 1992)

Structured Illumination Microscopy (SIM)

(Bailey et al. 1993)

$1994 \quad$ Green fluorescent protein as a marker for gene expression $\quad$ (Chalfie et al. 1994)

$1994 \quad 4$ pi microscope

(Hell 2003; Hell et al. 1994) 
Table 1 (continued)

\begin{tabular}{|c|c|c|}
\hline Year & Landmark & Author \\
\hline 1994 & Alignment and sensitive detection of DNA by a moving interface & (Bensimon et al. 1994) \\
\hline 1997 & The replication origin decision point is a mitogen & (Wu and Gilbert 1997) \\
\hline 1997 & $\begin{array}{l}\text { Dynamic molecular combing: stretching the whole human genome for } \\
\text { high-resolution studies. }\end{array}$ & (Michalet et al. 1997) \\
\hline 1998 & $\begin{array}{l}\text { Replicon clusters are stable units of chromosome structure evidence that nuclear } \\
\text { organization contributes to the efficient activation and propagation of S phase } \\
\text { in human cells }\end{array}$ & (Jackson and Pombo 1998) \\
\hline 1999 & $\begin{array}{l}\text { The spatial position and replication timing of chromosomal domains are both } \\
\text { established in early G1 phase }\end{array}$ & (Dimitrova and Gilbert 1999) \\
\hline 1999 & Single molecule analysis of DNA replication. & (Herrick and Bensimon 1999) \\
\hline 2000 & Heterogeneity of eukaryotic replicons, replicon clusters, and replication foci & (Berezney et al. 2000) \\
\hline 2000 & Dynamics of DNA replication factories in living cells & (Leonhardt et al. 2000) \\
\hline 2000 & DNA replication at high resolution & (Keck and Berger 2000) \\
\hline 2000 & Mechanisms of DNA replication & (Davey and O’Donnell 2000) \\
\hline 2001 & Eukaryotic origins & \\
\hline 2001 & $\begin{array}{l}\text { Repression of origin assembly in metaphase depends on inhibition of RLF-BCdt1 } \\
\text { by geminin }\end{array}$ & (Tada et al. 2001) \\
\hline 2001 & Visualization of DNA replication on individual Epstein-Barr Virus episomes & (Norio and Schildkraut 2001) \\
\hline 2002 & $\begin{array}{l}\text { DNA polymerase clamp shows little turnover at established replication sites but } \\
\text { sequential de novo assembly at adjacent origin clusters }\end{array}$ & (Sporbert et al. 2002) \\
\hline 2002 & DNA replication and chromatin & (Gerbi and Bielinsky 2002) \\
\hline 2002 & Initiation of DNA replication in multicellular eukaryotes & (Gerbi et al. 2002) \\
\hline 2003 & $\begin{array}{l}\text { Sequence-independent DNA binding and replication initiation by the human origin } \\
\text { recognition complex }\end{array}$ & (Vashee et al. 2003) \\
\hline 2003 & The 'ORC cycle': a novel pathway for regulating eukaryotic DNA replication & (DePamphilis 2003) \\
\hline 2004 & $\begin{array}{l}\text { Stable chromosomal units determine the spatial and temporal organization of DNA } \\
\text { replication }\end{array}$ & (Sadoni et al. 2004) \\
\hline 2004 & $\begin{array}{l}\text { DNA replication and DNA repair mechanisms most of the replication machinery is } \\
\text { also used in DNA repair. }\end{array}$ & (Sancar and Lindsey-Boltz 2004) \\
\hline 2005 & Preventing rereplication & (Blow and Dutta 2005) \\
\hline 2005 & $\begin{array}{l}\text { PCNA acts as a stationary loading platform for transiently interacting Okazaki } \\
\text { fragment maturation proteins }\end{array}$ & (Sporbert et al. 2005) \\
\hline 2005 & Eukaryotic origins of DNA replication: could you please be more specific? & (Cvetic and Walter 2005) \\
\hline 2006 & Origin selection and silent origins & (Patel et al. 2006) \\
\hline 2006 & Regulating the licensing of DNA replication origins in metazoa & (DePamphilis et al. 2006) \\
\hline 2006 & DNA replication: keep moving and don't mind the gap. & (Langston and O’Donnell 2006) \\
\hline 2007 & Impact of chromatin structure & \\
\hline 2007 & Replisome mechanics: insights into a twin DNA polymerase machine. & (Pomerantz and O’Donnell 2007) \\
\hline 2007 & The many faces of the origin recognition complex & (Sasaki and Gilbert 2007) \\
\hline 2007 & High-throughput mapping of origins of replication in human cells. & (Lucas et al. 2007) \\
\hline 2007 & Characterization of a triple DNA polymerase replisome. & (McInerney et al. 2007) \\
\hline 2007 & $\begin{array}{l}\text { Dynamic DNA helicase-DNA polymerase interactions assure processive } \\
\text { replication fork movement. }\end{array}$ & (Hamdan et al. 2007) \\
\hline 2007 & Polymerase switching in DNA replication. & (Lovett 2007) \\
\hline 2008 & 3D-SIM & (Gustafsson et al. 2008) \\
\hline 2008 & Division of labor at the eukaryotic replication fork. & (Nick McElhinny et al. 2008) \\
\hline 2008 & DNA polymerases at the replication fork in eukaryotes & (Stillman 2008) \\
\hline 2008 & Discovery of stimulated emission depletion (STED) & (Schmidt et al. 2008) \\
\hline 2009 & In DNA replication, the early bird catches the worm. & (Boye and Grallert 2009) \\
\hline 2009 & G-quadruplex structures: in vivo evidence and function. & (Lipps and Rhodes 2009) \\
\hline 2009 & Eukaryotic DNA replication control: lock and load, then fire. & (Remus and Diffley 2009) \\
\hline 2010 & Organization of DNA replication & (Chagin et al. 2010) \\
\hline
\end{tabular}


Table 1 (continued)

\begin{tabular}{lll}
\hline Year & Landmark & Author \\
\hline 2010 & Eukaryotic chromosome DNA replication: where, when, and how? & (Masai et al. 2010) \\
2010 & SCF (Cyclin F) controls centrosome homeostasis and mitotic fidelity through & (D'Angiolella et al. 2010) \\
& $\quad$ CP110 degradation. & (Yardimci et al. 2010) \\
2010 & Uncoupling of sister replisomes during eukaryotic DNA replication. & (Botchan and Berger 2010) \\
2010 & DNA replication: making two forks from one prereplication complex. & (Heller et al. 2011) \\
2011 & Eukaryotic origin-dependent DNA replication in vitro reveals sequential action of & DDK and S-CDK kinases. \\
2011 & Failure of origin activation in response to fork stalling leads to chromosomal & (Ozeri-Galai et al. 2011)
\end{tabular}

2011 Selective bypass of a lagging strand roadblock by the eukaryotic replicative DNA helicase.

2011 Genome-wide depletion of replication initiation events in highly transcribed regions.

2011 Origin association of Sld3, Sld7, and Cdc45 proteins is a key step for determination of origin-firing timing.

2012

Genome-scale identification of active DNA replication origins.

2012 Forkhead transcription factors establish origin timing and long-range clustering in S. cerevisiae

2012 A fragment based click chemistry approach towards hybrid G-quadruplex ligands: design, synthesis and biophysical evaluation

2012

2012

Histone hypoacetylation is required to maintain late replication timing of constitutive heterochromatin.

OriDB, the DNA replication origin database updated and extended.

2012

2012

Replication timing: the early bird catches the worm.

CK2 inhibitor CX-4945 suppresses DNA repair response triggered by

DNA-targeted anticancer drugs and augments efficacy: mechanistic rationale for drug combination therapy.

2012

Experimental approaches to identify cellular G-quadruplex structures and functions.

2012

2012

2012

2012

2012

2012

2013

2013

2013

2013

2013

2013
Activation of the replicative DNA helicase: breaking up is hard to do.

Analysis of DNA replication profiles in budding yeast and mammalian cells using DNA combing.

DeOri: a database of eukaryotic DNA replication origins.

Replication origins run (ultra) deep.

Unraveling cell type-specific and reprogrammable human replication origin signatures associated with G-quadruplex consensus motifs.

Targeted manipulation of heterochromatin rescues MeCP2 Rett mutants and re-establishes higher order chromatin organization.

Genome-wide mapping of human DNA-replication origins: levels of transcription at $\mathrm{ORC} 1$ sites regulate origin selection and replication timing.

Functional implications of genome topology.

Nuclear positioning.

Chromatin dynamics at the replication fork: there's more to life than histones.

Quantitative, genome-wide analysis of eukaryotic replication initiation and termination.

The Elg1 replication factor C-like complex functions in PCNA unloading during DNA replication.

Replication timing regulation of eukaryotic replicons: Rif1 as a global regulator of replication timing.

Bubble-seq analysis of the human genome reveals distinct chromatin-mediated mechanisms for regulating early- and late-firing origins.

A personal reflection on the replicon theory: from R1 plasmid to replication timing regulation in human cells.

From simple bacterial and archaeal replicons to replication N/U-domains.

Genomes and G-quadruplexes: for better or for worse.

New insights into replication clamp unloading.

Replication dynamics: biases and robustness of DNA fiber analysis.
(Fu et al. 2011)

(Martin et al. 2011)

(Tanaka et al. 2011)

(Cayrou et al. 2012)

(Knott et al. 2012)

(Ritson and Moses 2012)

(Casas-Delucchi et al. 2012)

(Siow et al. 2012)

(Douglas and Diffley 2012)

(Siddiqui-Jain et al. 2012)

(Di Antonio et al. 2012)

(Boos et al. 2012)

(Bianco et al. 2012)

(Gao et al. 2012)

(Gilbert 2012)

(Besnard et al. 2012)

(Casas-Delucchi et al. 2012)

(Dellino et al. 2013)

(Cavalli and Misteli 2013)

(Gundersen and Worman 2013)

(Whitehouse and Smith 2013)

(McGuffee et al. 2013)

(Kubota et al. 2013)

(Yamazaki et al. 2013)

(Mesner et al. 2013)

(Masai 2013)

(Hyrien et al. 2013)

(Tarsounas and Tijsterman 2013)

(Ulrich 2013)

(Técher et al. 2013) 
Table 1 (continued)

\begin{tabular}{|c|c|c|}
\hline Year & Landmark & Author \\
\hline 2013 & $\begin{array}{l}\text { Specification of DNA replication origins and genomic base composition in fission } \\
\text { yeasts. }\end{array}$ & (Mojardín et al. 2013) \\
\hline 2013 & $\begin{array}{l}\text { The replication domain model: regulating replicon firing in the context of } \\
\text { large-scale chromosome architecture. }\end{array}$ & (Pope and Gilbert 2013) \\
\hline 2013 & Time to be versatile: regulation of the replication timing program in budding yeast. & (Yoshida et al. 2013) \\
\hline 2013 & Why are there so many diverse replication machineries? & (Forterre 2013) \\
\hline 2014 & Epigenetic control of DNA replication dynamics in mammals & (Casas-Delucchi and Cardoso 2014) \\
\hline 2014 & Lethal effects of short-wavelength visible light on insects. & (Hori et al. 2014) \\
\hline 2014 & Existence and consequences of G-quadruplex structures in DNA. & (Murat and Balasubramanian 2014) \\
\hline 2014 & Histone variants: the tricksters of the chromatin world. & (Volle and Dalal 2014) \\
\hline 2014 & Supercoiling in DNA and chromatin. & (Gilbert and Allan 2014) \\
\hline 2014 & G4 motifs affect origin positioning and efficiency in two vertebrate replicators. & (Valton et al. 2014) \\
\hline 2014 & $\begin{array}{l}\text { The spatiotemporal program of DNA replication is associated with specific } \\
\text { combinations of chromatin marks in human cells. }\end{array}$ & (Picard et al. 2014) \\
\hline 2014 & $\begin{array}{l}\text { Licensing of DNA replication, cancer, pluripotency and differentiation: an } \\
\text { interlinked world? }\end{array}$ & (Champeris Tsaniras et al. 2014) \\
\hline 2014 & $\begin{array}{l}\text { Temporal and spatial regulation of eukaryotic DNA replication: from regulated } \\
\text { initiation to genome-scale timing program. }\end{array}$ & (Renard-Guillet et al. 2014) \\
\hline 2014 & The histone variant $\mathrm{H} 2 \mathrm{~A}$. Bbd is enriched at sites of DNA synthesis. & (Sansoni et al. 2014) \\
\hline 2014 & FANCJ promotes DNA synthesis through G-quadruplex structures. & (Castillo Bosch et al. 2014) \\
\hline 2015 & The hunt for origins of DNA replication in multicellular eukaryotes. & (Urban et al. 2015) \\
\hline 2015 & Measuring the effectiveness of scientific gatekeeping. & (Siler et al. 2015) \\
\hline 2015 & Peaks cloaked in the mist: the landscape of mammalian replication origins. & (Hyrien 2015) \\
\hline 2015 & $\begin{array}{l}\text { Post-translational modifications of tubulin: pathways to functional diversity of } \\
\text { microtubules. }\end{array}$ & (Song and Brady 2015) \\
\hline 2015 & Regulated eukaryotic DNA replication origin firing with purified proteins. & (Yeeles et al. 2015) \\
\hline 2015 & $\begin{array}{l}\text { Single-molecule studies of origin licensing reveal mechanisms ensuring } \\
\text { bidirectional helicase loading. }\end{array}$ & (Ticau et al. 2015) \\
\hline 2015 & Single-molecule visualization of MCM2-7 DNA loading: seeing is believing. & (Chistol and Walter 2015) \\
\hline 2015 & $\begin{array}{l}\text { High-resolution profiling of Drosophila replication start sites reveals a DNA shape } \\
\text { and chromatin signature of metazoan origins. }\end{array}$ & (Comoglio et al. 2015) \\
\hline 2015 & $\begin{array}{l}\text { The dynamics of eukaryotic replication initiation: origin specificity, licensing, and } \\
\text { firing at the single-molecule level. }\end{array}$ & (Duzdevich et al. 2015) \\
\hline 2016 & $\begin{array}{l}\text { 4D Visualization of replication foci in mammalian cells corresponding to } \\
\text { individual replicons }\end{array}$ & (Chagin et al. 2016) \\
\hline 2016 & $\begin{array}{l}\text { 3D replicon distributions arise from stochastic initiation and domino-like DNA } \\
\text { replication progression }\end{array}$ & (Löb et al. 2016) \\
\hline
\end{tabular}

\section{Always look on the bright side}

Along came Aequorea victoria green fluorescent protein (Shimomura et al. 1962) and brought light into darkness. Where audioradiography once ruled (Huberman and Riggs 1966; Huberman and Riggs 1968; Taylor et al. 1957), immunofluorescence labeling of fixed cells with monoclonal antibodies to modified nucleotides incorporated into newly synthesized DNA took the stage (e.g., Aten et al. 1992; Cardoso et al. 1993; Jackson and Pombo 1998; Jaunin et al. 1998; Ma et al. 1998; Mazzotti et al. 1990; Nakamura et al. 1986; Raska et al. 1989; Raska et al. 1991) only to be outshined by live cell microscopy of fluorescent fusion proteins (Cardoso et al. 1997; Leonhardt et al. 2000). Cell cycle duration (Van Dilla et al. 1969), fork speed, replication rate, and replicon sizes (Kriegstein and Hogness 1974; Taylor 1977; Taylor and Hozier 1976; Wilson and Wilson 1975; Yurov 1977; Yurov 1978; Yurov 1979; Yurov and Liapunova 1977) were all unearthed from the dark.

In parallel, the first affordable home computers made digital image analysis possible through the help of Wayne S. Rasband who developed the milestone in image analysis ImageJ (then, NIH Image) in 1987 (Schneider et al. 2012).

Extensive microscopic analysis in fixed cells followed and provided a spatiotemporal description of replication sites (replication foci; see Fig. 2) in cells throughout S-phase (Nakamura et al. 1986) along with the three main distinctive early, mid, and late S-phase replication foci patterns (Jackson 


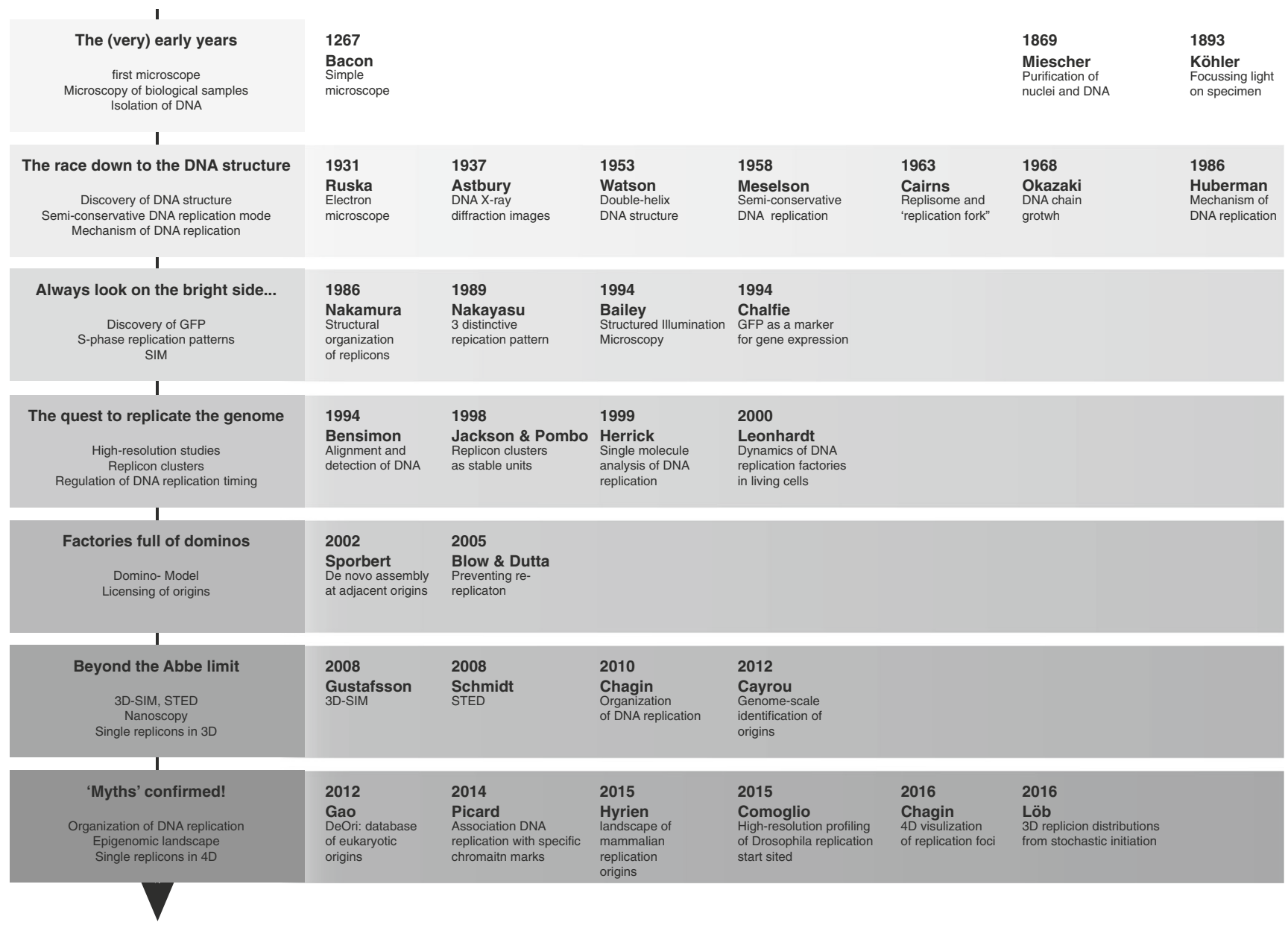

Fig. 1 Graphical overview of microscopy developments and their impact on DNA replication studies

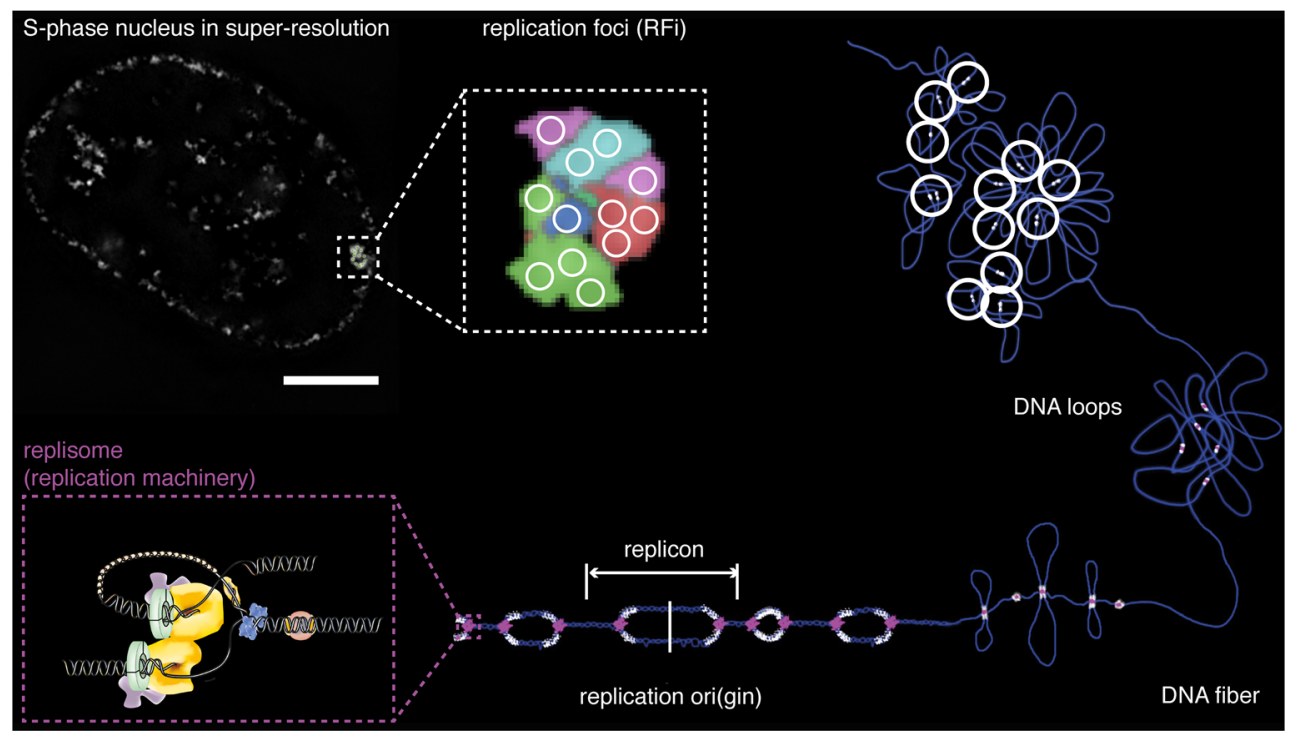

Fig. 2 Organization of DNA replication from the genome to the individual replisome/replicon. A fluorescently labeled human HeLa Kyoto cell with a typical late S-phase replication pattern is presented in the top left corner (scale bar $=5 \mu \mathrm{m}$ ). Magnified super-resolution replication foci, with white circles representing individual replication sites displayed in the middle of the top row. A scheme of clustered
DNA loops with active replication sites (white) is shown on the right. Starting point of DNA replication, the replication origin (ori), and the region replicated from a single origin displayed in the bottom row. Each replicon is replicated by two replication machineries (magenta), composed of various replication proteins, magnified in the bottom left corner. Adapted from (Chagin et al. 2016; Chagin et al. 2010) 
and Pombo 1998; Mills et al. 1989; Nakayasu and Berezney 1989). Alongside, replication origins (Burhans et al. 1990; Burhans et al. 1991) were also reported.

\section{The quest to replicate the genome}

DNA loops (see Fig. 2) and their "functional" attachments to active transcription units were shown as chromatin organizers during mitosis (Jackson et al. 1992), and replication factories were proposed as clusters of DNA replication sites organized by the nucleoskeleton (Hozák et al. 1993). Molecular combing, refined DNA fiber analysis, and sensitive detection of DNA (Bensimon et al. 1994) opened the door to whole genome stretching and high-resolution studies (Michalet et al. 1997). It allowed analysis of single DNA molecules undergoing replication (see Fig. 2) in a much greater resolution (Herrick and Bensimon 1999) than ever before. Stable replicon clusters were also described as a basis for effective activation and propagation of genome replication during S-phase (Jackson and Pombo 1998) and regulation of replication timing (Dimitrova and Gilbert 1999).

Studies on DNA replication proteins (see Fig. 2) using livecell fluorescence microscopy produced time lapse movies of replication factories and elucidated basic principles of their dynamic assembly-disassembly behavior (Leonhardt et al. 2000). Different regulatory levels were shown to be necessary to initiate and regulate DNA replication. Not only the chromatin structure, nuclear, and chromosomal locations but also origin recognition complex (ORC) and a whole bunch of other factors were found to define start sites of replication (DePamphilis 2003; Gerbi and Bielinsky 2002; Gerbi et al. 2002; Sasaki and Gilbert 2007).

\section{Factories full of dominos}

In addition to the "factory model" (Hozák et al. 1993), more dynamic models ensued (Sadoni et al. 2004; Sporbert et al. 2002) whereby replication at one site induces domino-like activation of neighboring origins, without the need to postulate pre-determined clusters of replicons. The combination with an earlier model postulating that origins of replication would be licensed only during mitosis and this license to replicate would be revoked after one round of replication (Blow and Dutta 2005; Blow and Laskey 1988) elegantly demonstrated how DNA is completely duplicated once, and only once, during each cell cycle. Despite Cvetic wishing for "eukaryotic origins of DNA replication to please be more specific" (Cvetic and Walter 2005), DNA replication origins in higher eukaryotes have been at best elusive. Nonetheless, as a whole, DNA replication is a very robust mechanism and stalled forks can be reactivated or reactivate neighboring origins to close all gaps and provide a perfect copy of billions of nucleotides at every cell division (Langston and O'Donnell 2006; Patel et al. 2006).

\section{The ever elusive origin}

The hunt for the elusive consensus motif of DNA replication origins continued with genome-wide high throughput mapping of potential origins and next-generation sequencing methods (Besnard et al. 2012; Cadoret et al. 2008; Cayrou et al. 2012; Dellino et al. 2013; Karnani et al. 2010; Lucas et al. 2007; Martin et al. 2011; Mesner et al. 2013; Mesner et al. 2011; Mukhopadhyay et al. 2014; Picard et al. 2014; Valenzuela et al. 2011) but stalled without a conclusive definition of the mammalian origin of replication. Correlations with specialized DNA structures (e.g., G-quadruplexes) and many others have been suggested but there seems not to be a simple solution and potentially there is no need to have one.

Studies into the epigenomic landscape, epigenetic control of DNA replication, and higher order chromatin organization (Casas-Delucchi and Cardoso 2011; Casas-Delucchi et al. 2012) have provided a link of epigenetic modifications (in particular, histone acetylation level) and temporal control of DNA replication origin firing.

Altogether, even Hyrien's "Peaks cloaked in the mist," all out approach was not able to identify possible origins by similarities in thousands of microarrays and/or next-generation sequencing data, suggesting origins form at unspecific DNA sites, but are suppressed by ongoing transcription (Hyrien 2015), which is highly correlated with histone acetylation.

\section{To go where no one has gone before: beyond the Abbe limit}

Meanwhile, the microscopy arms race to and beyond the diffraction limit calculated by Abbe continued with the Structured Illumination Microscopy (SIM) (Bailey et al. 1993), the 3D-SIM (Gustafsson et al. 2008) and the stimulated emission depletion (STED) (Schmidt et al. 2008).

The first attempts to label dating back to 1986 (Nakamura et al. 1986) and quantify replication sites in cells yielded numbers on the low hundreds (see Fig. 3). A decade later with the advent of digital imaging and computational image analysis tools, these numbers grew to around one thousand (Berezney et al. 1996; Fox et al. 1991; Jackson and Pombo 1998; Ma et al. 1998), where they remained for several years (see Fig. 3). Such numbers of replication sites were compatible with a concept of clusters of replicons activated together and, thus, visualized together.

The dramatic increase in spatial resolution made possible with the new super-resolution microscopy techniques 
Fig. 3 Graphical overview of replication foci numbers in correlation with microscopy developments

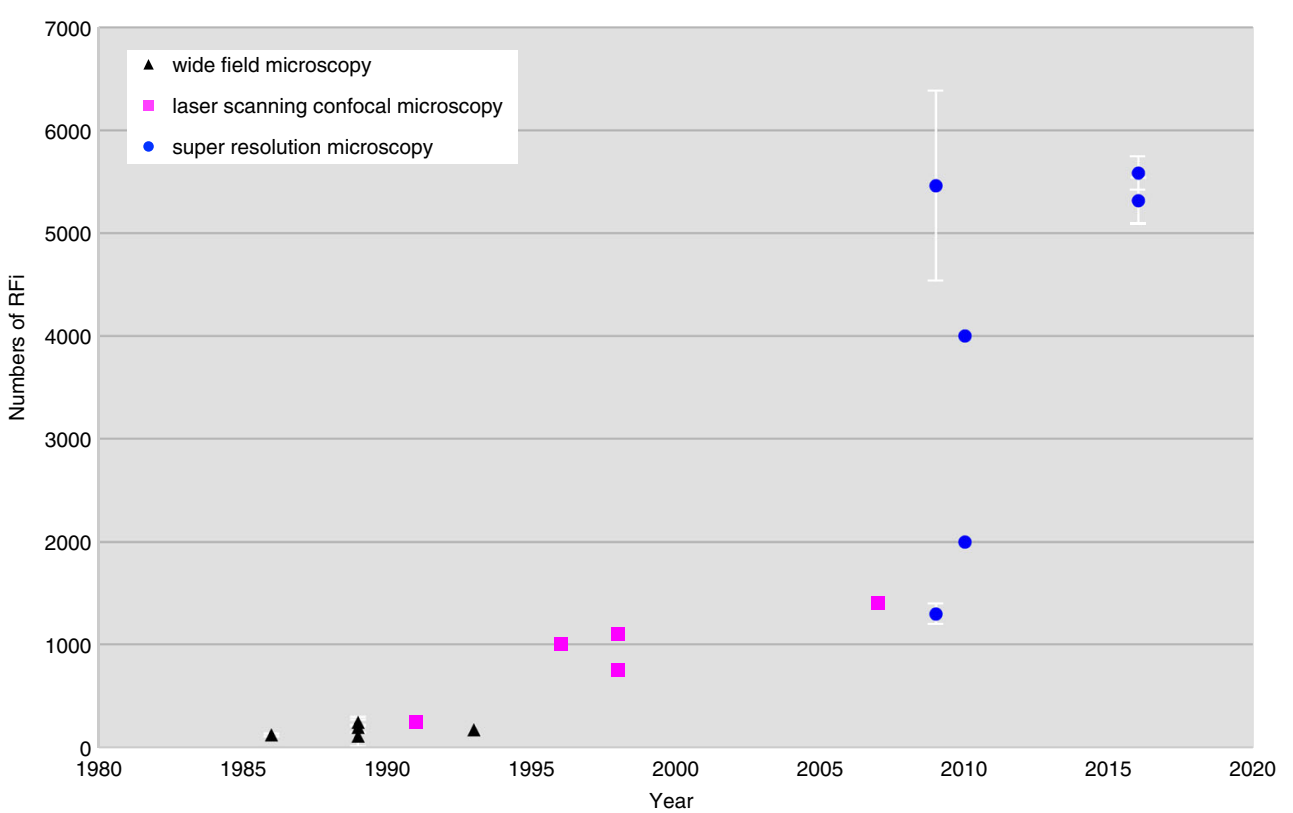

(fluorescence nanoscopy) enabled the visualization, for the first time, of smaller replication structures (Baddeley et al. 2010; Cseresnyes et al. 2009; Ligasová et al. 2009). It was now possible to resolve structures well below the Abbe limit, down to $30 \mathrm{~nm}$ and smaller. Nanoscopy (Gustafsson et al. 2008; Hell 2003; Hell et al. 1994) is in full swing and let us go where no one has gone before: beyond the Abbe limit. This, on the other hand, created another level of demand upon image analysis tools.

\section{"Myths" confirmed!}

The stage was now set to try and unveil the units of genome replication, i.e., the replicons and their associated machinery, the replisome, in cells.

From the earlier studies using light nanoscopy techniques (Baddeley et al. 2010; Cseresnyes et al. 2009) as well as electron microscopy (Koberna et al. 2005), suitable computational image analysis protocols were developed (Chagin et al. 2015). These combined efforts led to a further increase in the numbers of replication sites measured in cells (see Fig. 3), which was now finally compatible and fitting with the predicted numbers of replicons needed to duplicate the genome in human cells (Chagin et al. 2016; Löb et al. 2016).

The microscopic information age had arrived. Previous efforts by Shaw et al. (2010), together with measurements throughout the years culminating on the visualization and quantification of individual replicons in cells in 4D, all supported by 3D-SIM imaging (Chagin et al. 2016) were all combined in a minimalistic but comprehensive 4D replicon simulation model (Löb et al. 2016) displaying previously published replication polarity gradients, replication timing profiles, N/U domains, topologically associating domains, and timing transition regions (Audit et al. 2013; Baker et al. 2012; Chen et al. 2010; Hyrien et al. 2013; Pope et al. 2014).

\section{Journey into the future}

Future work should aim to bridge the ever-increasing genomewide population data, with single molecule and single-cell microscopic data. Novel ways to combine and relate these very different types of information should be developed to get the highest spatial together with the highest temporal resolution without compromising the data on variability between single cells.

Importantly, the available models should be put to work to predict and test genome replication in different cell types and species and under different stress conditions. This would unleash the value of the existing models and lead us into the in silico DNA replication era.

Acknowledgements We apologize to the colleagues whose work was not cited due to space constraints. We thank all the past and present members of our laboratory for their many contributions along the years. Last but not least, we thank our collaborators over the years, which have made our work so much more enjoyable.

Our research has been supported by grants of the German Research Foundation (DFG), the Volkswagen Foundation, and the German Ministry for Education and Research (BMBF).

Conflict of interest The authors declare that they have no conflict of interest. 
Open Access This article is distributed under the terms of the Creative Commons Attribution 4.0 International License (http:// creativecommons.org/licenses/by/4.0/), which permits unrestricted use, distribution, and reproduction in any medium, provided you give appropriate credit to the original author(s) and the source, provide a link to the Creative Commons license, and indicate if changes were made.

\section{References}

Astbury WT (1947) X-ray studies of nucleic acids. SYM SOC EXP BIOL 1:66-76

Aten JA, Bakker PJ, Stap J, Boschman GA, Veenhof CH (1992) DNA double labelling with IdUrd and CldUrd for spatial and temporal analysis of cell proliferation and DNA replication. Histochem J 24:251-259

Audit B et al (2013) Multiscale analysis of genome-wide replication timing profiles using a wavelet-based signal-processing algorithm. Nat Protoc 8:98-110

Bacon R (1267) Opus Majus. Vatican Library, Vatican

Baddeley D et al (2010) Measurement of replication structures at the nanometer scale using super-resolution light microscopy. Nucleic Acids Res 38:e8-e8

Bailey B, Farkas DL, Taylor DL, Lanni F (1993) Enhancement of axial resolution in fluorescence microscopy by standing-wave excitation. Nature 366:44-48

Baker A, Chen CL, Julienne H, Audit B, d'Aubenton-Carafa Y, Thermes C, Arneodo A (2012) Linking the DNA strand asymmetry to the spatio-temporal replication program. EUR PHYS J E 35

Bensimon A, Simon A, Chiffaudel A, Croquette V, Heslot F, Bensimon D (1994) Alignment and sensitive detection of DNA by a moving interface. Science 265:2096-2098

Berezney R, Dubey DD, Huberman JA (2000) Heterogeneity of eukaryotic replicons, replicon clusters, and replication foci. Chromosoma 108:471-484

Berezney R et al (1996) Connecting nuclear architecture and genomic function. J Cell Biochem 62:223-226

Besnard E et al (2012) Unraveling cell type-specific and reprogrammable human replication origin signatures associated with G-quadruplex consensus motifs. Nat Struct Mol Biol 19:837-844

Bianco JN et al (2012) Analysis of DNA replication profiles in budding yeast and mammalian cells using DNA combing. Methods 57:149157

Blow JJ, Dutta A (2005) Preventing re-replication of chromosomal DNA. NAT REV MOL CELL BIO 6:476-486

Blow JJ, Laskey RA (1988) A role for the nuclear envelope in controlling DNA replication within the cell cycle. Nature 332:546-548

Boos D, Frigola J, Diffley J (2012) Activation of the replicative DNA helicase: breaking up is hard to do. Curr Opin Cell Biol 24:423-430

Botchan M, Berger J (2010) DNA replication: making two forks from one prereplication complex. Mol Cell 40:860-861

Boye E, Grallert B (2009) In DNA replication, the early bird catches the worm. Cell 136:812-814

Burhans WC, Vassilev LT, Caddle MS, Heintz NH, DePamphilis ML (1990) Identification of an origin of bidirectional DNA replication in mammalian chromosomes. Cell 62:955-965

Burhans WC, Vassilev LT, Wu J, Sogo JM, Nallaseth FS, DePamphilis ML (1991) Emetine allows identification of origins of mammalian DNA replication by imbalanced DNA synthesis, not through conservative nucleosome segregation. EMBO J 10:4351-4360

Cadoret J-C et al (2008) Genome-wide studies highlight indirect links between human replication origins and gene regulation. P NATL ACAD SCI USA 105:15837-15842
Cairns J (1963) The bacterial chromosome and its manner of replication as seen by autoradiography. J Mol Biol 6:208-213

Cardoso MC, Joseph C, Rahn H-P, Reusch R, Nadal-Ginard B, Leonhardt H (1997) Mapping and use of a sequence that targets DNA ligase I to sites of DNA replication In Vivo. J Cell Biol 139:579

Cardoso MC, Leonhardt H, Nadal-Ginard B (1993) Reversal of terminal differentiation and control of DNA replication: cyclin a and cdk2 specifically localize at subnuclear sites of DNA replication. Cell 74: 979-992

Casas-Delucchi CS, Cardoso MC (2011) Epigenetic control of DNA replication dynamics in mammals. Nucleus 2:370-382

Casas-Delucchi CS, Becker A, Bolius JJ, Cardoso MC (2012) Targeted manipulation of heterochromatin rescues MeCP2 Rett mutants and re-establishes higher order chromatin organization. Nucleic Acids Res 40:e176-e176

Casas-Delucchi CS et al (2012) Histone hypoacetylation is required to maintain late replication timing of constitutive heterochromatin. Nucleic Acids Res 40:159-169

Castillo Bosch P, Segura-Bayona S, Koole W, van Heteren JT, Dewar JM, Tijsterman M, Knipscheer P (2014) FANCJ promotes DNA synthesis through G-quadruplex structures. EMBO J 33:2521-2533

Cavalli G, Misteli T (2013) Functional implications of genome topology. Nat Struct Mol Biol 20:290-299

Cayrou C, Grégoire D, Coulombe P, Danis E, Méchali M (2012) Genome-scale identification of active DNA replication origins. Methods 57:158-164

Chagin VO et al (2016) 4D visualization of replication foci in mammalian cells corresponding to individual replicons. Nat Commun 7:11231

Chagin VO, Reinhart M, Cardoso MC (2015) High-resolution analysis of mammalian DNA replication units. METH MOL BIOL 1300:43-65

Chagin VO, Stear JH, Cardoso MC (2010) Organization of DNA replication. Cold Spring Harb Perspect Biol 2:a000737-a000737

Chalfie M, Tu Y, Euskirchen G, Ward WW, Prasher DC (1994) Green fluorescent protein as a marker for gene expression. Science 263: 802-805

Champeris Tsaniras S, Kanellakis N, Symeonidou IE, Nikolopoulou P, Lygerou Z, Taraviras S (2014) Licensing of DNA replication, cancer, pluripotency and differentiation: an interlinked world? Semin Cell Dev Biol 30:174-180

Chen C-L et al (2010) Impact of replication timing on non-CpG and CpG substitution rates in mammalian genomes. Genome Res 20:447-457

Chistol G, Walter JC (2015) Single-molecule visualization of MCM2-7 DNA loading: seeing is believing. Cell 161:429-430

Comoglio F, Schlumpf T, Schmid V, Rohs R, Beisel C, Paro R (2015) High-resolution profiling of drosophila replication start sites reveals a DNA shape and chromatin signature of metazoan origins. Cell Rep $11: 821-834$

Cseresnyes Z, Schwarz U, Green CM (2009) Analysis of replication factories in human cells by super-resolution light microscopy. BMC CELL BIOL 10:88

Cvetic C, Walter JC (2005) Eukaryotic origins of DNA replication: could you please be more specific? Semin Cell Dev Biol 16:343-353

D'Angiolella V et al (2010) SCF(cyclin F) controls centrosome homeostasis and mitotic fidelity through CP110 degradation. Nature 466: $138-142$

Dahm R (2008) Discovering DNA: Friedrich Miescher and the early years of nucleic acid research. vol 122. Human Genetics, vol 6 . Springer-Verlag,

Danna KJ, Nathans D (1972) Bidirectional replication of simian virus 40 DNA. P NATL ACAD SCI USA 69:3097-3100

Davey MJ, O'Donnell M (2000) Mechanisms of DNA replication. Curr Opin Chem Biol 4:581-586

Dellino GI et al (2013) Genome-wide mapping of human DNAreplication origins: levels of transcription at ORC1 sites regulate origin selection and replication timing. Genome Res 23:1-11 
DePamphilis ML (2003) The 'ORC cycle': a novel pathway for regulating eukaryotic DNA replication. Gene 310:1-15

DePamphilis ML, Blow JJ, Ghosh S, Saha T, Noguchi K, Vassilev A (2006) Regulating the licensing of DNA replication origins in metazoa. Curr Opin Cell Biol 18:231-239

Di Antonio M, Rodriguez R, Balasubramanian S (2012) Experimental approaches to identify cellular G-quadruplex structures and functions. Methods 57:84-92

Dimitrova DS, Gilbert DM (1999) The spatial position and replication timing of chromosomal domains are both established in early G1 phase. Mol Cell 4:983-993

Douglas ME, Diffley J (2012) Replication timing: the early bird catches the worm. Curr Biol 22:R81-R82

Duzdevich D, Warner MD, Ticau S, Ivica NA, Bell SP, Greene EC (2015) The dynamics of eukaryotic replication initiation: origin specificity, licensing, and firing at the single-molecule level. Mol Cell 58:483494

Egger MD, Petráň M (1967) New reflected-light microscope for viewing unstained brain and ganglion cells. Science 157:305-307

Forterre P (2013) Why are there so many diverse replication machineries? J Mol Biol 425:4714-4726

Fox MH, Arndt-Jovin DJ, Jovin TM, Baumann PH, Robert-Nicoud M (1991) Spatial and temporal distribution of DNA replication sites localized by immunofluorescence and confocal microscopy in mouse fibroblasts. J Cell Sci 99(Pt 2):247-253

Fu YV et al (2011) Selective bypass of a lagging strand roadblock by the eukaryotic replicative DNA helicase. Cell 146:931-941

Galilei G (1610) Sidereus nuncius. Apud Thomam Baglionum, Venedig

Gao F, Luo H, Zhang CT (2012) DeOri: a database of eukaryotic DNA replication origins. Bioinformatics 28:1551-1552

Gerbi SA, Bielinsky A-K (2002) DNA replication and chromatin. CURR OPIN GENET DEV 12:243-248

Gerbi SA, Strezoska Z, Waggener JM (2002) Initiation of DNA replication in multicellular eukaryotes. J Struct Biol 140:17-30

Gilbert DM (2012) Replication origins run (ultra) deep. Nat Struct Mol Biol 19:740-742

Gilbert N, Allan J (2014) Supercoiling in DNA and chromatin. CURR OPIN GENET DEV 25:15-21

Gundersen GG, Worman HJ (2013) Nuclear positioning. Cell 152:13761389

Gustafsson MGL et al (2008) Three-dimensional resolution doubling in wide-field fluorescence microscopy by structured illumination. Biophys J 94:4957-4970

Haeckel E (1866) Generelle Morphologie der Organismen: allgemeine Grundzuge der organischen Formen-Wissenschaft, mechanisch begrundet durch die von Charles Darwin reformirte DescendenzTheorie., vol 1. Georg Reimer, Berlin

Hamdan SM et al (2007) Dynamic DNA helicase-DNA polymerase interactions assure processive replication fork movement. Mol Cell 27:539-549

Hell SW (2003) Toward fluorescence nanoscopy. Nat Biotechnol 21: $1347-1355$

Hell SW, Stelzer EHK, Lindek S, Cremer C (1994) Confocal microscopy with an increased detection aperture: type-B 4Pi confocal microscopy. Opt Lett 19:222

Heller RC, Kang S, Lam WM, Chen S, Chan CS, Bell SP (2011) Eukaryotic origin-dependent DNA replication in vitro reveals sequential action of DDK and S-CDK kinases. Cell 146:80-91

Herrick J, Bensimon A (1999) Single molecule analysis of DNA replication. Biochimie 81:859-871

Hooke R (1665) Micrographia, or, Some physiological descriptions of minute bodies made by magnifying glasses: with observations and inquiries thereupon. J. Martyn and J. Allestry., London

Hori M, Shibuya K, Sato M, Saito Y (2014) Lethal effects of shortwavelength visible light on insects. Scientific Reports 4:7383
Hozák P, Hassan AB, Jackson DA, Cook PR (1993) Visualization of replication factories attached to nucleoskeleton. Cell 73:361-373

Huberman JA, Riggs AD (1966) Autoradiography of chromosomal DNA fibers from Chinese hamster cells. P NATL ACAD SCI USA 55: 599-606

Huberman JA, Riggs AD (1968) On the mechanism of DNA replication in mammalian chromosomes. J Mol Biol 32:327-341

Hyrien O (2015) Peaks cloaked in the mist: the landscape of mammalian replication origins. J Cell Biol 208:147-160

Hyrien O et al (2013) From simple bacterial and archaeal replicons to replication N/U-domains. J Mol Biol 425:4673-4689

Jackson DA, Dolle A, Robertson G, Cook PR (1992) The attachments of chromatin loops to the nucleoskeleton. CELL BIOL INT REP 16: 687-696

Jackson DA, Pombo A (1998) Replicon clusters are stable units of chromosome structure: evidence that nuclear organization contributes to the efficient activation and propagation of S phase in human cells. J Cell Biol 140:1285-1295

Jaunin F, Visser AE, Cmarko D, Aten JA, Fakan S (1998) A new immunocytochemical technique for ultrastructural analysis of DNA replication in proliferating cells after application of two halogenated deoxyuridines. J Histochem Cytochem 46:1203-1209

Karnani N, Taylor CM, Malhotra A, Dutta A (2010) Genomic study of replication initiation in human chromosomes reveals the influence of transcription regulation and chromatin structure on origin selection. Mol Biol Cell 21:393-404

Keck JL, Berger JM (2000) DNA replication at high resolution. CHEM BIOL 7:R63-R71

Knoll M, Ruska E (1932a) Beitrag zur geometrischen Elektronenoptik. I. ANN PHYS-BERLIN 404:607-640. doi:10.1002/andp.19324040506

Knoll M, Ruska E (1932b) Beitrag zur geometrischen Elektronenoptik. II. ANN PHYS-BERLIN 404:641-661. doi:10.1002/andp.19324040602

Knott SRV et al (2012) Forkhead transcription factors establish origin timing and long-range clustering in S. Cerevisiae. Cell 148:99-111

Koberna K et al (2005) Electron microscopy of DNA replication in 3-D: evidence for similar-sized replication foci throughout S-phase. J Cell Biochem 94:126-138

Köhler A (1893) Ein neues Beleuchtungsverfahren für mikrophotographische Zwecke. vol 10. vol 4. Zeitschrift fur wissenschaftliche Mikroskopie und fur mikroskopische Technik., Stuttgart

Kriegstein HJ, Hogness DS (1974) Mechanism of DNA replication in drosophila chromosomes: structure of replication forks and evidence for bidirectionality. P NATL ACAD SCI USA 71:135

Kubota T, Nishimura K, Kanemaki MT, Donaldson AD (2013) The Elg1 replication factor $\mathrm{C}$-like complex functions in PCNA unloading during DNA replication. Mol Cell 50:273-280

Langston LD, O'Donnell M (2006) DNA replication: keep moving and don't mind the gap. Mol Cell 23:155-160

Leonhardt H, Rahn HP, Weinzierl P, Sporbert A, Cremer T, Zink D, Cardoso MC (2000) Dynamics of DNA replication factories in living cells. J Cell Biol 149:271-280

Ligasová A, Raska I, Koberna K (2009) Organization of human replicon: singles or zipping couples? J Struct Biol 165:204-213

Lipps HJ, Rhodes D (2009) G-quadruplex structures: in vivo evidence and function. Trends Cell Biol 19:414-422

Löb D, Lengert N, Chagin VO, Reinhart M, Casas-Delucchi CS, Cardoso MC, Drossel B (2016) 3D replicon distributions arise from stochastic initiation and domino-like DNA replication progression. Nat Commun 7:11207

Lovett ST (2007) Polymerase switching in DNA replication. Mol Cell 27: 523-526

Lucas I, Palakodeti A, Jiang Y, Young DJ, Jiang N, Fernald AA, Le Beau MM (2007) High-throughput mapping of origins of replication in human cells. EMBO Rep 8:770-777 
Ma H, Samarabandu J, Devdhar RS, Acharya R, Cheng PC, Meng C, Berezney R (1998) Spatial and temporal dynamics of DNA replication sites in mammalian cells. J Cell Biol 143:1415-1425

Martin MM et al (2011) Genome-wide depletion of replication initiation events in highly transcribed regions. Genome Res 21:1822-1832

Masai H (2013) A personal reflection on the replicon theory: from R1 plasmid to replication timing regulation in human cells. J Mol Biol 425:4663-4672

Masai H, Matsumoto S, You Z, Yoshizawa-Sugata N, Oda M (2010) Eukaryotic chromosome DNA replication: where, when, and how? Annu Rev Biochem 79:89-130

Mazzotti G et al (1990) High-resolution detection of newly synthesized DNA by anti-bromodeoxyuridine antibodies identifies specific chromatin domains. J Histochem Cytochem 38:13-22

McGuffee SR, Smith DJ, Whitehouse I (2013) Quantitative, genomewide analysis of eukaryotic replication initiation and termination. Mol Cell 50:123-135

McInerney P, Johnson A, Katz F, O’Donnell M (2007) Characterization of a triple DNA polymerase replisome. Mol Cell 27:527-538

Mendel G (1866) Versuche über Pflanzen-Hybriden, vol 4. Verhandlungen des naturforschenden Vereins Brünn, Brünn

Meselson M, Stahl FW (1958) The replication of DNA in Escherichia coli. P NATL ACAD SCI USA 44:671-682

Mesner LD, Valsakumar V, Cieslik M, Pickin R, Hamlin JL, Bekiranov S (2013) Bubble-seq analysis of the human genome reveals distinct chromatin-mediated mechanisms for regulating early- and late-firing origins. Genome Res 23:1774-1788

Mesner LD, Valsakumar V, Karnani N, Dutta A, Hamlin JL, Bekiranov S (2011) Bubble-chip analysis of human origin distributions demonstrates on a genomic scale significant clustering into zones and significant association with transcription. Genome Res 21:377-389

Michalet X et al (1997) Dynamic molecular combing: stretching the whole human genome for high-resolution studies. Science 277: $1518-1523$

Miescher JF (1871) Ueber die chemische Zusammensetzung der Eiterzellen. vol 4: 441-60. Medicinsich-chemische Untersuchungen, Felix Hoppe-Seyler, Berlin: Hirschwald

Mills AD, Blow JJ, White JG, Amos WB, Wilcock D, Laskey RA (1989) Replication occurs at discrete foci spaced throughout nuclei replicating in vitro. J Cell Sci 94:471

Minsky M (1961) Microscopy Apparatus, US Patent 3,103,467. Washington, DC: U.S. Unite States of America Patent

Mojardín L, Vázquez E, Antequera F (2013) Specification of DNA replication origins and genomic base composition in fission yeasts. $\mathrm{J}$ Mol Biol 425:4706-4713

Mukhopadhyay R et al (2014) Allele-specific genome-wide profiling in human primary erythroblasts reveal replication program organization. PLoS Genet 10:e1004319

Murat P, Balasubramanian S (2014) Existence and consequences of Gquadruplex structures in DNA. CURR OPIN GENET DEV 25:2229

Nakamura H, Morita T, Sato C (1986) Structural organizations of replicon domains during DNA synthetic phase in the mammalian nucleus. Exp Cell Res 165:291-297

Nakayasu H, Berezney R (1989) Mapping replicational sites in the eucaryotic cell nucleus. J Cell Biol 108:1-11

Nick McElhinny SA, Gordenin DA, Stith CM, Burgers PMJ, Kunkel TA (2008) Division of labor at the eukaryotic replication fork. Mol Cell 30:137-144

Norio P, Schildkraut CL (2001) Visualization of DNA replication on individual Epstein-Barr virus Episomes. Science 294:2361-2364

O'Keefe RT, Henderson SC, Spector DL (1992) Dynamic organization of DNA replication in mammalian cell nuclei: spatially and temporally defined replication of chromosome-specific alpha-satellite DNA sequences. J Cell Biol 116:1095-1110
Okazaki R, Okazaki T, Sakabe K, Sugimoto K, Sugino A (1968) Mechanism of DNA chain growth. I. Possible discontinuity and unusual secondary structure of newly synthesized chains. P NATL ACAD SCI USA 59:598-605

Okazaki T, Okazaki R (1969) Mechanism of DNA chain growth. IV. Direction of synthesis of T4 short DNA chains as revealed by exonucleolytic degradation. P NATL ACAD SCI USA 64:12421248

Ozeri-Galai E, Lebofsky R, Rahat A, Bester AC, Bensimon A, Kerem B (2011) Failure of origin activation in response to fork stalling leads to chromosomal instability at fragile sites. Mol Cell 43:122-131

Patel PK, Arcangioli B, Baker SP, Bensimon A, Rhind N (2006) DNA replication origins fire stochastically in fission yeast. Mol Biol Cell 17:308-316

Petráň M, Hadravský M, Egger MD, Galambos R (1968) Tandemscanning reflected-light microscope. J Opt Soc Am 58:661-664

Picard F et al (2014) The spatiotemporal program of DNA replication is associated with specific combinations of chromatin marks in human cells. PLoS Genet 10:e1004282

Pomerantz RT, O’Donnell M (2007) Replisome mechanics: insights into a twin DNA polymerase machine. Trends Microbiol 15:156-164

Pope BD, Gilbert DM (2013) The replication domain model: regulating replicon firing in the context of large-scale chromosome architecture. J Mol Biol 425:4690-4695

Pope BD et al (2014) Topologically associating domains are stable units of replication-timing regulation. Nature 515:402-405

Raska I, Koberna K, Jarník M, Petrasovicová V, Bednár J, Raska K, Bravo R (1989) Ultrastructural immunolocalization of cyclin/ PCNA in synchronized 3 T3 cells. Exp Cell Res 184:81-89

Raska I et al (1991) Ultrastructural cryoimmunocytochemistry is a convenient tool for the study of DNA replication in cultured cells. J ELECTRON MICR TECH 18:91-105

Remus D, Diffley JFX (2009) Eukaryotic DNA replication control: lock and load, then fire. Curr Opin Cell Biol 21:771-777

Renard-Guillet C, Kanoh Y, Shirahige K, Masai H (2014) Temporal and spatial regulation of eukaryotic DNA replication: from regulated initiation to genome-scale timing program. Semin Cell Dev Biol 30:110-120

Ritson DJ, Moses JE (2012) A fragment based click chemistry approach towards hybrid G-quadruplex ligands: design, synthesis and biophysical evaluation. Tetrahedron 68:197-203

Rizzoli R et al (1992) DNA synthesis progression in 3 T3 synchronized fibroblasts: a high resolution approach. Histochemistry 97:181-187

Sadoni N, Cardoso MC, Stelzer EHK, Leonhardt H, Zink D (2004) Stable chromosomal units determine the spatial and temporal organization of DNA replication. J Cell Sci 117:5353-5365

Sancar A, Lindsey-Boltz LA (2004) Molecular mechanisms of mammalian DNA repair and the DNA damage checkpoints. Annu Rev Biochem 73:39-85

Sansoni V et al (2014) The histone variant H2A.Bbd is enriched at sites of DNA synthesis. Nucleic Acids Res 42:6405-6420

Sasaki T, Gilbert DM (2007) The many faces of the origin recognition complex. Curr Opin Cell Biol 19:337-343

Schmidt R, Wurm CA, Jakobs S, Engelhardt J, Egner A, Hell SW (2008) Spherical nanosized focal spot unravels the interior of cells. Nat Methods 5:539-544

Schneider CA, Rasband WS, Eliceiri KW (2012) NIH image to ImageJ: 25 years of image analysis. Nat Methods 9:671-675

Shaw A, Olivares-Chauvet P, Maya-Mendoza A, Jackson DA (2010) Sphase progression in mammalian cells: modelling the influence of nuclear organization. Chromosom Res 18:163-178

Shimomura O, Johnson FH, Saiga Y (1962) Extraction, purification and properties of Aequorin, a bioluminescent protein from the luminous hydromedusan, Aequorea. J CELL COMPAR PHYSL 59:223-239

Siddiqui-Jain A et al (2012) CK2 inhibitor CX-4945 suppresses DNA repair response triggered by DNA-targeted anticancer drugs and 
augments efficacy: mechanistic rationale for drug combination therapy. Mol Cancer Ther 11:994-1005

Siler K, Lee K, Bero L (2015) Measuring the effectiveness of scientific gatekeeping. P NATL ACAD SCI USA 112:360-365

Singer C (1914) Notes on the early history of microscopy. P ROY SOC MED 7:247-279

Siow CC, Nieduszynska SR, Müller CA, Nieduszynski CA (2012) OriDB, the DNA replication origin database updated and extended. Nucleic Acids Res 40:D682-D686

Song Y, Brady ST (2015) Post-translational modifications of tubulin: pathways to functional diversity of microtubules. Trends Cell Biol $25: 125-136$

Soyfer VN (2001) The consequences of political dictatorship for Russian science. NAT REV GENET 2:723-729

Sporbert A, Domaing P, Leonhardt H, Cardoso MC (2005) PCNA acts as a stationary loading platform for transiently interacting Okazaki fragment maturation proteins. Nucleic Acids Res 33:3521-3528

Sporbert A, Gahl A, Ankerhold R, Leonhardt H, Cardoso MC (2002) DNA polymerase clamp shows little turnover at established replication sites but sequential de novo assembly at adjacent origin clusters. Mol Cell 10:1355-1365

Stillman B (2008) DNA polymerases at the replication fork in eukaryotes. Mol Cell 30:259-260

Sugimoto K, Okazaki T, Imae Y, Okazaki R (1969) Mechanism of DNA chain growth, III. Equal annealing of T4 nascent short DNA chains with the separated complementary strands of the phage DNA. P NATL ACAD SCI USA 63:1343-1350

Sugimoto K, Okazaki T, Okazaki R (1968) Mechanism of DNA chain growth, II. Accumulation of newly synthesized short chains in E. Coli infected with ligase-defective T4 phages. P NATL ACAD SCI USA 60:1356-1362

Tada S, Li A, Maiorano D, Méchali M, Blow JJ (2001) Repression of origin assembly in metaphase depends on inhibition of RLF-B/Cdt1 by geminin. Nat Cell Biol 3:107-113

Tanaka S, Nakato R, Katou Y, Shirahige K, Araki H (2011) Origin association of Sld3, Sld7, and Cdc45 proteins is a key step for determination of origin-firing timing. Curr Biol 21:2055-2063

Tarsounas M, Tijsterman M (2013) Genomes and G-quadruplexes: for better or for worse. J Mol Biol 425:4782-4789

Taylor JH (1977) Increase in DNA replication sites in cells held at the beginning of S phase. Chromosoma 62:291-300

Taylor JH, Hozier JC (1976) Evidence for a four micron replication unit in CHO cells. Chromosoma 57:341-350

Taylor JH, Woods PS, Hughes WL (1957) The organization and duplication of chromosomes as revealed by autoradiographic studies using tritium-labeled thymidinee. P NATL ACAD SCI USA 43:122-128

Técher $\mathrm{H}$ et al (2013) Replication dynamics: biases and robustness of DNA fiber analysis. J Mol Biol 425:4845-4855

Ticau S, Friedman LJ, Ivica NA, Gelles J, Bell SP (2015) Singlemolecule studies of origin licensing reveal mechanisms ensuring bidirectional helicase loading. Cell 161:513-525
Ulrich HD (2013) New insights into replication clamp unloading. J Mol Biol 425:4727-4732

Urban JM, Foulk MS, Casella C, Gerbi SA (2015) The hunt for origins of DNA replication in multicellular eukaryotes. F1000Prime Reports 7

Valenzuela MS et al (2011) Preferential localization of human origins of DNA replication at the 5 -ends of expressed genes and at evolutionarily conserved DNA sequences. PLoS One 6:e17308

Valton A-L et al (2014) G4 motifs affect origin positioning and efficiency in two vertebrate replicators. EMBO J 33:732-746

van der Aa AJ (1851) Biografisch Woordenboek der Nederlanden. J. J. van Brederode,

Van Dilla MA, Truiullo TT, Mullaney PF, Coultex JR (1969) Cell microfluorometry: a method for rapid fluorescence measurement. Science 163:1213

Vashee S, Cvetic C, Lu W, Simancek P, Kelly TJ, Walter JC (2003) Sequence-independent DNA binding and replication initiation by the human origin recognition complex. GENE DEV 17:1894-1908

Volle C, Dalal Y (2014) Histone variants: the tricksters of the chromatin world. CURR OPIN GENET DEV 25:8-14

Watson JD, Crick FH (1953) Molecular structure of nucleic acids; a structure for deoxyribose nucleic acid. Nature 171:737-738

Whitehouse I, Smith DJ (2013) Chromatin dynamics at the replication fork: there's more to life than histones. CURR OPIN GENET DEV 23:140-146

Wilson B, Wilson BG (1975) DNA replication in the amphibia. Chromosoma 51

Wu JR, Gilbert DM (1997) The replication origin decision point is a mitogen-independent, 2-aminopurine-sensitive, G1-phase event that precedes restriction point control. Mol Cell Biol 17:4312-4321

Yamazaki S, Hayano M, Masai H (2013) Replication timing regulation of eukaryotic replicons: Rifl as a global regulator of replication timing. Trends Genet 29:449-460

Yardimci H, Loveland AB, Habuchi S, van Oijen AM, Walter JC (2010) Uncoupling of sister replisomes during eukaryotic DNA replication. Mol Cell 40:834-840

Yeeles JTP, Deegan TD, Janska A, Early A, Diffley JFX (2015) Regulated eukaryotic DNA replication origin firing with purified proteins. Nature 519:431-435

Yoshida K, Poveda A, Pasero P (2013) Time to be versatile: regulation of the replication timing program in budding yeast. J Mol Biol 425: 4696-4705

Yurov YB (1977) DNA replication in human diploid cells of different origin. CELL DIFFER DEV 6:i-ii

Yurov YB (1978) Replication of chromosomal DNA in cultured abnormal human cells. Hum Genet 43:47-52

Yurov YB (1979) The rate of fork movement during DNA replication in mammalian cells. Chromosoma 74:347-353

Yurov YB, Liapunova NA (1977) The units of DNA replication in the mammalian chromosomes: evidence for a large size of replication units. Chromosoma 60:253-267

Zernike F (1955) How I discovered phase contrast. Science 121:345-349 